УДК $332.1 ; 338.2$

ДИВЕРСИФИКАЦИЯ ЭКОНОМИКИ МАЛЫХ МОНОГОРОДОВ: РОЛЬ СЕТЕВЫХ

ВЗАИМОДЕЙСТВИЙ

марина Ю. Шерешева ${ }^{1, @, *}$

\author{
${ }^{1}$ Московский государственный университет им. М. В. Ломоносова, 119991, Россия, г. Москва, Ленинские \\ Горы, 1 \\ @m.sheresheva@mail.ru
}

Поступила в редакиию 02.03.2018. Принята к печати 27.03.2018.

Ключевые слова: моногорода, малые города, диверсификация, сетевые взаимодействия, региональное развитие.
Аннотация: Предметом данной статьи является диверсификация экономики малых моногородов, целью - выявление роли сетевых взаимодействий в этом процессе. В данной статье представлены предварительные результаты проекта РНФ «Устойчивое развитие экономики территорий на основе сетевого взаимодействия малых городов и районных центров», направленного на выявление возможностей преодоления нарастающего разрыва в уровне и качестве жизни населения малых городов России в сравнении с населением крупных городов и мегаполисов, на разработку комплекса мер по комбинированию ресурсов и компетенций малых городов в рамках сетевого взаимодействия. Исследование проводится на примере Тульской и Владимирской областей, Пермского края. Для достижения поставленной цели использовался комплекс методов, включая метод системного анализа, формально-логический метод, диалектический метод познания экономических и социальных процессов, а также количественные и качественные маркетинговые исследования, что позволяет сделать определенные выводы о наличии структурных проблем и тенденций, характерных для современного периода, и предложить рекомендации с учетом специализации городов. Выявлены серьезные проблемы, с которыми сталкиваются муниципалитеты моногородов, и препятствия на пути результативного межмуниципального взаимодействия. В то же время, как показывает международная практика, формирование благоприятной институциональной среды для взаимовыгодного комбинирования ресурсов и компетенций малых городов с разной специализацией способствует реализации совместных проектов и позволяет ускорить процессы диверсификации экономики за счет преимуществ сетевого механизма координации.

Для цитирования: Шерешева М. Ю. Диверсификация экономики малых моногородов: роль сетевых взаимодействий // Вестник Кемеровского государственного университета. Серия: Политические, социологические и экономические науки. 2018. № 2. С. 162-171. DOI:10.21603/2500-3372-2018-2-162-171.

Моногорода (монофпрофильные города) - муниципальные образования, в развитии которых определяющую роль играют градообразующие предприятия (ГРОП), на которых либо работает не менее 25 \% экономически активного населения города, либо производится не менее половины валового продукта города [1]. Более $45 \%$ российских малых городов являются монопрофильными [2]. Особенно значительна их доля в таких федеральных округах РФ, как Уральский $Ф О$, Сибирский ФО, Северо-Западный ФО, Приволжский ФО [3]. Так, в Пермском крае 10 из 18 малых городов (в список моногородов Пермского края включены также поселки городского типа (Теплая Гора, Уральский, Пашия, Юго-Камский)) являются монопрофильными, во Владимирской области моногородами являются 7 из 18 малых городов, в Тульской области - 5 из 13 [4]. Важное значение моногородов для экономики России обусловлено не только большой долей проживающего в них населения (порядка $10 \%$ всего населения РФ), но и тем фактом, что для них характерна повышенная уязвимость к различного рода шокам, которая может вызвать «эффект домино» [5; 6]. Потери, которые понесли такие города в постсоветский период, особенно сильно сказались на качестве жизни населения [7;8]. Последствия кризиса дополнительно обострили сложившуюся ситуацию, однако, как справедливо подчеркивает Е. М. Петрикова, кризис был лишь катализатором тех финансовых, правовых и социальных проблем российских моногородов, которые накапливались десятилетиями [9].

Безусловно, существуют серьезные различия между многочисленными российскими моногородами.

\footnotetext{
* Статья подготовлена в рамках научных исследований, выполняемых при финансовой поддержке гранта Российского научного фонда (проект № 17-18-01324) «Устойчивое развитие экономики территорий на основе сетевого взаимодействия малых городов и районных центров».
} 
Согласно ранжированию моногородов по уровню напряженности социально-экономической ситуации (расчет на основе показателей: Уровень безработицы; Величина доходов на душу населения; Прогноз изменения показателей на 1 год на основе макрофакторов (8 параметров) и с учетом отраслевых индексов [4]), проведенному Фондом развития моногородов, в 75 из 319 моногородов (почти 25 \%) ситуация достаточно стабильна [4]. Однако большинство малых моногородов РФ остро нуждаются в новых способах адаптации к современным реалиям, привлечения инвестиций, развития городской инфраструктуры [10].

На совещании по вопросу развития монопрофильных муниципальных образований России, состоявшемся в марте 2017 г. в г. Алексин (Тульская область) на базе градообразующего предприятия АО «Тяжпроарматура», Министр экономического развития РФ М. Орешкин подчеркнул, что развитие моногородов является одним из приоритетных направлений стратегического развития России и предполагает создание новых рабочих мест на предприятиях и развитие новых инвестиционных проектов [11]. При этом речь идет не только, а иногда не столько о производствах, которые исторически являлись градообразующими, сколько о диверсификации экономики этих городов. (При наличии разных подходов и определений, в самом общем виде под диверсификацией экономики подразумевается процесс, направленный на увеличение разнообразия видов экономической деятельности [12]). Так, до конца 2018 г. в 319 монопрофильных муниципальных образованиях страны, большинство из которых являются малыми городами, планируется создать около 250 тыс. новых рабочих мест, не связанных с градообразующими предприятиями, до 2025 г. - 600 тыс. [11].

В текущем десятилетии существенно расширилось участие институтов развития в финансировании проектов, направленных на диверсификацию экономики моногородов. В первую очередь это касается финансирования инфраструктурных проектов. Свой вклад вносят Фонд развития моногородов, Фонд развития промышленности, Корпорация малых и средних предприятий, бюджеты всех уровней и др. Так, Фонд развития промышленности предоставляет моногородам до 500 млн руб. под 3,5-5 \% годовых, Минпромтог РФ и федеральные целевые программы выделяют несколько меньшие объемы финансирования (в основном порядка 100-200 млн руб.) [13]. В 2015-2017 гг. Фондом развития моногородов заключены 76 генеральных соглашений в отношении 100 моногородов, при этом в отношении 28 моногородов из 19 регионов РФ заключены также соглашения о софинансировании. Среди них 13 городов Приволжского ФО, по 5 городов Центрального и Сибирского ФО, по 2 города Северо-Западного и Уральского ФО, а также один город Северо-Кавказского ФО (таблица 1).

С 2016 г. модернизация моногородов является приоритетным национальным проектом, в рамках которого реализуется, в частности, разработанная в 2013 г. программа «Пять шагов благоустройства», нацеленная на кардинальное повышение комфортности жизни в этих городах и включающая следующие этапы [14]:

- благоустройство оживленного общественного пространства

- создание возможностей для времяпрепровождения молодёжи

- обновление городских достопримечательностей

- обновление или создание объектов социальной инфраструктуры

- активация заброшенных или неэффективно используемых зданий и помещений

В целом можно говорить о том, что начато целенаправленное формирование системы институтов поддержки развития монопрофильных городов, однако пока не удается создать условия для полноценного решения проблем этих муниципальных образований, особенно моногородов с наиболее сложным социально-экономическим положением. По-прежнему сохраняется их моноцентричность и связанные с этим высокие риски $[15 ; 6]$.

Таблица 1. Объем средств, выделенных Фондом развития моногородов в рамках соглашений о софинансировании, заключенных в 2015-2017 гг. [4]

Table 1. The volume of funds allocated by the Single-Industry Cities' Development Fund in the framework of co-financing agreements, 2015-2017 [4]

\begin{tabular}{|l|l|c|c|c|}
\hline \multicolumn{1}{|c|}{ Регион } & \multicolumn{1}{|c|}{ Моногород } & $\begin{array}{c}\text { Объем принятых } \\
\text { обязательств ФРМ } \\
\text { с учетом ДС, } \\
\text { тыс. руб. (до 2022 г.) }\end{array}$ & $\begin{array}{c}\text { Объем } \\
\text { инвестиций, } \\
\text { тыс. руб. } \\
\text { (до 2022 г.) }\end{array}$ & $\begin{array}{c}\text { Объем } \\
\text { рабочих мест, } \\
\text { человек } \\
\text { (до 2022 г.) }\end{array}$ \\
\hline Алтайский край & Заринск & 46650,08 & 1608000,00 & 142 \\
\hline $\begin{array}{l}\text { Республика } \\
\text { Башкортостан }\end{array}$ & Кумертау & 250252,52 & 4313000,00 & 520 \\
\hline Белебей & 238669,37 & 2610000,00 & 334 \\
\hline Владимирская область & Камешково & 598440,47 & 8523473,00 & 988 \\
\hline Вологодская область & Череповец & 809913,40 & 5094000,00 & 1030 \\
\hline Воронежская область & Павловск & 1019102,086 & 11301315,17 & 1006 \\
\hline Республика Дагестан & Каспийск & 606586,08 & 2361000,00 & 850 \\
\hline
\end{tabular}




\begin{tabular}{|c|c|c|c|c|}
\hline Регион & Моногород & $\begin{array}{c}\text { Объем принятых } \\
\text { обязательств ФРМ } \\
\text { с учетом ДС, } \\
\text { тыс. руб. (до } 2022 \text { г.) }\end{array}$ & $\begin{array}{c}\text { Объем } \\
\text { инвестиций, } \\
\text { тыс. руб. } \\
\text { ( до 2022 г.) }\end{array}$ & $\begin{array}{c}\text { Объем } \\
\text { рабочих мест, } \\
\text { человек } \\
\text { (до } 2022 \text { г.) } \\
\end{array}$ \\
\hline \multirow{2}{*}{ Ивановская область } & Вичуга & 441494,23 & $2082867^{*}$ & 533 \\
\hline & Наволоки & 252261,996 & 732167,00 & 850 \\
\hline Республика Карелия & Надвоицы & 225482,69 & 1965000,00 & 484 \\
\hline \multirow{3}{*}{ Кемеровская область } & Анжеро-судженск & 982939,21 & 6834740,00 & 2381 \\
\hline & Таштагол & 271333,68 & 450000,00 & 182 \\
\hline & Юрга & 129318,28 & 677232,00 & 302 \\
\hline \multirow{2}{*}{ Кировская область } & Белая холуница & 241840,88 & 1141860,00 & 442 \\
\hline & Луза & 174801,07 & 638048,00 & 576 \\
\hline Пензенская область & Сердобск & 44237,50 & 1359777,00 & 162 \\
\hline Свердловская область & Краснотурьинск & 581977,91 & 11874200,00 & 2149 \\
\hline Тамбовская область & Котовск & 25916,82 & 176627,00 & 70 \\
\hline \multirow{5}{*}{ Республика Татарстан } & \begin{tabular}{|l|} 
Набережные челны \\
(дорожная инфраструк- \\
тура 2015-2016 гг.) \\
\end{tabular} & 573949,36 & 8624100,00 & 3438 \\
\hline & $\begin{array}{l}\text { Набережные челны, } \\
\text { (создание промпарка } \\
\text { "развитие") } \\
\end{array}$ & 124657,55 & 340000,00 & 170 \\
\hline & Зеленодольск & 861820,14 & 9457300,00 & 2206 \\
\hline & \begin{tabular}{|l|} 
Набережные челны \\
(дорожная инфраструк- \\
тура 2017-2018 гг.) \\
\end{tabular} & 98430,54 & 652135,50 & 105 \\
\hline & Нижнекамск & 335381,97 & 1052693,00 & 262 \\
\hline Томская область & Северск & 265096,809 & 1228217,00 & 170 \\
\hline Удмуртская Республика & Сарапул & 82600,84 & 160000,00 & 100 \\
\hline Ульяновская область & Димитровград & 83336,43 & 1510000,00 & 215 \\
\hline Челябинская область & Усть-катав & 1593863,08 & 5750176,45 & 720 \\
\hline Чувашская Республика & Канаш & 459010,68 & 1510640,00 & 381 \\
\hline
\end{tabular}

Говоря о механизмах диверсификации, которыми могут воспользоваться российские моногорода, многие авторы акцентируют внимание на создании территорий опережающего социально-экономического развития, на разработке и реализации масштабных инвестиционных проектов государственно-частного партнёрства $[13 ; 16-18]$. Упоминаются в этом контексте и вопросы кооперации, хотя при этом, как правило, имеются в виду межфирменные кооперационные связи, в то время как вопросы межмуниципального взаимодействия в большинстве случаев остаются на периферии внимания российских авторов.

В. Л. Тамбовцев указывает на существование четырех разных типов межмуниципальных взаимодействий: (1) конкуренция, (2) кооперация, (3) коопкуренция (совмещение конкуренции и кооперации), (4) слияние (объединение) муниципалитетов, которое можно рассматривать как «предельную» форму взаимодействия [19]. По сути, в данном случае муниципалитеты городов выступают аналогами действующих на рынке компаний, вступающих в разного рода взаимодействия, в том числе в рамках сетевых структур.
Соответственно, города рассматриваются как экономические субъекты, разрабатывающие собственную стратегию развития, конкурирующие между собой и сотрудничающие друг с другом [20]. В этом смысле можно говорить о «предпринимательском городе» (entrepreneurial city) как полноправном участнике ceтевого взаимодействия на уровне региона, страны или группы стран и о применимости сетевой парадигмы «для интерпретации макроскопического пространственного поведения коллективных агентов, таких как города, конкурирующих и взаимодействующих на мировой арене» [21, p. 498].

В рамках этой парадигмы пересматривается роль малых городов в обеспечении устойчивого регионального развития [22-24]. Современный подход к пониманию устойчивого регионального развития предполагает повышение качества жизни населения региона, включая жителей всех населенных пунктов, без нанесения ущерба качеству жизни будущих поколений $[25 ; 26]$. Как подчеркивает целый ряд авторов, устойчивость обеспечивается наличием и взаимодействием большого числа конкурентоспособных городов разного 
размера с разной специализацией, взаимодействие которых позволяет решать сложные метапроблемы, такие как приспосабливаемость к изменению климата, эффективность использования ресурсов, преодоление бедности, и т. д. [27; 28]. Так, целый ряд исследований показал особое значение малых городов для преодоления бедности и диверсификации сельских территорий $[29 ; 30]$. В частности, анализ данных кросс-культурной панели, в которую входила 51 развивающаяся страна, позволяет утверждать, что люди находят для себя возможности в небольших близко находящихся городах легче и быстрее, чем в отдаленных крупных городах [31]. То есть диверсификация сельской экономики на основе развития небольших городов (secondary town development) ведет к более инклюзивным паттернам роста, нежели развитие метрополий (metropolitization), и способствует более широкому, хотя и более медленному, процессу роста [29].

Что касается диверсификации экономики самих малых городов, то, как показывает международная практика, ее успех зависит от степени вовлеченности местных и региональных властей в формирование институциональной среды, способствующей сетевому взаимодействию стейкхолдеров территории [32; 33; 24]. В условиях, когда для последовательного решения проблем малых моногородов нужно «создание механизмов адаптивности к изменениям во внешней среде без масштабной и систематической федеральной ресурсной поддержки» [6; 34], возрастает роль сетевых механизмов координации в формировании устойчивых экономических связей между муниципальными образованиями разных размеров как ключевыми стейкхолдерами единого экономического пространства территории.

Сетевое взаимодействие позволяет комбинировать взаимодополняющие ресурсы моногородов и благодаря этому повышать общий объем ресурсов (в том числе финансовых) для совместного решения задач, которые не под силу отдельным муниципалитетам. При этом необходим тщательный анализ сложившейся специализации и ресурсного потенциала городов, на основе которого может быть принято решение о включении в сетевое взаимодействие на основе потенциальной специализации (она может остаться прежней либо быть изменена).

В качестве примера можно привести обобщенные характеристики ряда малых моногородов Пермского края (таблица 2).

Таблица 2. Малые моногорода Пермского Края [14]

Table 2. Small single-industry towns in the Perm region [14]

\begin{tabular}{|l|c|c|l|}
\hline \multicolumn{1}{|c|}{ Город } & Год основания & $\begin{array}{c}\text { Население } \\
\text { (тыс. человек) }\end{array}$ & \multicolumn{1}{c|}{ Градообразующее предприятие } \\
\hline Александровск & 1783 & 14,0 & $\begin{array}{l}\text { ОАО «Александровский машиностроительный } \\
\text { завод» }\end{array}$ \\
\hline Красновишерск & 1894 & 15,8 & 3АО «Уралалмаз» \\
\hline Нытва & 1756 & 19,0 & ОАО «Нытва» \\
\hline Очер & 1759 & 14,2 & ОАО «Очерский машиностроительный завод» \\
\hline Чусовой & 1878 & 50,2 & ОАО «Чусовской металлургический завод» \\
\hline
\end{tabular}

Эти города, возникшие еще в XVIII-XIX вв., исторически сформировались как центры промышленного производства и добычи полезных ископаемых. Так, города Александровск и Нытва со времен Советского Союза остаются центрами машиностроения, хотя их социально-экономическое положение и привлекательность для рабочей силы и населения значительно ухудшились. Город Красновишерск является моногородом и центром целлюлозно-бумажной промышленности, постепенно восстанавливающим темпы развития. Анализ возможных направлений диверсификации малых моногородов Пермского края показывает, что в ряде случаев целесообразна опора на их сложившуюся специализацию, однако в большинстве случаев необходим акцент на диверсификацию их экономики с учетом перспективной специализации (таблица 3 ).

Из таблицы 3 видно, что одним из направлений диверсификации экономики малых моногородов со сложным социально-экономическим положением является развитие туристско-рекреационной сферы. Даже в случае слабой транспортной доступности существуют возможности привлечения туристов - в частности, развитие таких видов, как активный, промышленный, приключенческий туризм. Однако в целом задача развития транспортной инфраструктуры и повышения транспортной доступности малых городов является общей для большинства российских регионов, требует интенсивной работы над ее решением, в том числе как один из факторов успешной диверсификации.

Малые моногорода Владимирской области (таблица 4) находятся в гораздо более выгодном положении с точки зрения транспортной доступности, и это создает более благоприятные условия для их включения в сетевое межмуниципальное взаимодействие. Как и в случае Пермского края, диверсификация экономики этих городов может опираться на реализацию туристского потенциала, особенно с учетом опыта целого ряда малых городов Владимирской области, входящих в «Золотое кольцо России», и возможностей развития разнообразных видов туризма и туристских маршрутов. Кроме того, Администрация Владимирской области в текущем десятилетии уделяет растущее внимание развитию туризма, турпоток ежегодно растет (в 2016 г. он превысил 4 млн туристов, в том числе более 250 тыс. иностранных) [35]. 
Таблица 3. Сложившаяся и потенциальная специализация малых моногородов Пермского края [24]

Table 3. Current and potential specialization of small single-industry towns in the Perm region [24]

\begin{tabular}{|l|l|l|}
\hline $\begin{array}{c}\text { Малые города } \\
\text { Пермского края }\end{array}$ & \multicolumn{1}{|c|}{ Сложившаяся специализация } & \multicolumn{1}{|c|}{ Потенциальная специализация } \\
\hline Александровск & Промышленность & $\begin{array}{l}\text { Транспортная, туристско-рекреацинная } \\
\text { Развитое транспортное сообщение, трасса } \\
\text { регионального значения: Соликамск - Чу- } \\
\text { совой - Кунгур }\end{array}$ \\
\hline Красновишерск & $\begin{array}{l}\text { Промышленность - моногород со сложным } \\
\text { социально-экономическим положением }\end{array}$ & $\begin{array}{l}\text { Туристско-рекреационная } \\
\text { Слабая транспортная доступность }\end{array}$ \\
\hline Нытва & $\begin{array}{l}\text { Промышленность - моногород со сложным } \\
\text { социально-экономическим положением }\end{array}$ & $\begin{array}{l}\text { Туристско-рекреационная } \\
\text { Слабая транспортная доступность }\end{array}$ \\
\hline Очер & $\begin{array}{l}\text { Промышленность - моногород со сложным } \\
\text { социально-экономическим положением }\end{array}$ & $\begin{array}{l}\text { Туристско-рекреационная } \\
\text { Слабая транспортная доступность }\end{array}$ \\
\hline Чусовой & Промышленность & $\begin{array}{l}\text { Транспортная, туристско-рекреационная, } \\
\text { промышленная }\end{array}$ \\
\hline
\end{tabular}

Таблица 4. Моногорода Владимирской области [14] Table 4. Single-industry towns in the Vladimir region [14]

\begin{tabular}{|l|c|c|l|}
\hline \multicolumn{1}{|c|}{ Город } & $\begin{array}{c}\text { Год } \\
\text { основания }\end{array}$ & $\begin{array}{c}\text { Население } \\
\text { (тыс. человек) }\end{array}$ & \multicolumn{1}{c|}{ Градообразующее предприятие } \\
\hline Камешково & 1892 & 12,7 & Камешковский филиал ООО «Детская одежда». \\
\hline Кольчугино & 1871 & 44,1 & $\begin{array}{l}\text { ОАО «Электрокабель Кольчугинский завод», 3АО «Кольчу- } \\
\text { гинский завод цветных металлов». }\end{array}$ \\
\hline Ставрово & 1515 & 7,7 & ООО «СтиС-Владимир» \\
\hline Курлово & 1811 & 6,3 & ООО «Завод Символ» \\
\hline Меленки & 1700 & 14,3 & ООО «Литмаш-М». \\
\hline Вязники & 1608 & 43,1 & ОАО «Освар» \\
\hline Гороховец & 1158 & 13,2 & ООО «Русджам» \\
\hline
\end{tabular}

В качестве примера активного развития туристско-рекреационной специализации моногорода можно привести Гороховец - один из немногих городов Центральной России, где сохранилась старинная планировка, 3 монастыря и 7 церквей, гражданская архитектура XVII века, более поздние памятники архитектуры (купеческие дома), а также памятники археологии. Производство стекла и стеклянных изделий, на котором специализируется градообразующее предприятие ООО "Русджам", не способно решить проблемы развития города. В этой связи Администрация Владимирской области приняла решение кардинально изменить ситуацию и поставила целью диверсификацию экономики Гороховца с акцентом на включение в единое культурно-туристическое пространство России. В качестве катализатора выбрано празднование 850 -летнего юбилея Гороховца, подготовка к которому используется для повышения узнаваемости города и интереса к нему как туристской дестинации (Министерство культуры РФ рассматривает Гороховец в качестве возможного пилотного проекта по созданию города-музея), а также для решения целого ряда инфраструктурных задач, реставрации и сохранение объектов культурно-исторического наследия. В числе девяти городов России Гороховец вошел в совместный проект Министерства культуры РФ и Международного банка реконструкции и развития "Сохранение и развитие малых исторических городов и поселений". Ведется работа по включению исторического центра г. Гороховец в список объектов Всемирного наследия ЮНЕСКО. Примечательно также, что в рамках исполнения Указа Президента РФ «О праздновании 850-летия основания города Гороховца» и поручений Губернатора Владимирской области инициируется подписание соглашений о сотрудничестве между администрациями муниципальных образований и районов области (так, 30 января 2018 г. подписано соглашение между Гороховецким и Камешковским районами). [36].

В целом предварительный анализ социально-экономического состояния и ресурсного потенциала малых моногородов Пермского края, Владимирской области и Тульской области, проведенный в 2017 г. в рамках проекта РНФ «Устойчивое развитие экономики территорий на основе сетевого взаимодействия малых городов и районных центров», свидетельствует, что проблемы малых моногородов острее, однако их характер и пути решения сходны и вписываются 
в общую картину состояния и развития малых городов [37; 38]. В таблице 5 приведены примеры решения ряда общих проблем малых моногородов на основе сетевого взаимодействия.

Таблица 5. Возможности сетевого взаимодействия для развития малых моногородов Table 5. Possibilities of networking in development of single-industry towns

\begin{tabular}{|c|c|}
\hline Проблема & Роль сетевого взаимодействия \\
\hline $\begin{array}{l}\text { Дефицит финансовых ресурсов, необхо- } \\
\text { димых для реализации социальных и } \\
\text { коммерческих проектов }\end{array}$ & $\begin{array}{l}\text { Совместное использование финансовых ресурсов муниципальных } \\
\text { образований в рамках согласованных сетевых проектов, направ- } \\
\text { ленных на реализацию наиболее актуальных социально-экономи- } \\
\text { ческих задач }\end{array}$ \\
\hline $\begin{array}{l}\text { Дефицит квалифицированных кадров при } \\
\text { серьезных проблемах трудоустройства }\end{array}$ & $\begin{array}{l}\text { Совместное планирование и реализация программ поддержки } \\
\text { молодых специалистов, комплексных программ обучения и } \\
\text { переобучения кадров с учетом потребностей каждого отдельного } \\
\text { моногорода и региона в целом, с маршрутизацией обучения в } \\
\text { более крупных городах } \\
\text { Обмен лучшими практиками по формированию городской } \\
\text { инфраструктуры и городского пространства, привлекательного } \\
\text { для жизни }\end{array}$ \\
\hline $\begin{array}{l}\text { Отсутствие единого подхода к оценке } \\
\text { госпрограмм, отклонение в ходе их } \\
\text { реализации от плановых целевых } \\
\text { показателей }\end{array}$ & $\begin{array}{l}\text { Координация действий по выполнению программ и достижению } \\
\text { целевых показателей развития, концентрация усилий в наиболее } \\
\text { перспективных «точках совместного приложения сил» }\end{array}$ \\
\hline Транспортно-логистические проблемы & $\begin{array}{l}\text { Формирование логистических сетей, в рамках которых малые } \\
\text { города получат доступ к полноценной транспортной инфраструк- } \\
\text { туре и, как результат, более широкие возможности комбинирова- } \\
\text { ния ресурсов, реализации продукции и расширения спектра услуг }\end{array}$ \\
\hline $\begin{array}{l}\text { Отсутствие полноценной статистической } \\
\text { информации и данных о ресурсном } \\
\text { потенциале по отдельным муниципаль- } \\
\text { ным образованиям }\end{array}$ & $\begin{array}{l}\text { Создание единой информационной базы, объединяющей стати- } \\
\text { стику и ключевые показатели, необходимые для оценки состояния } \\
\text { экономики и социальной сферы малых городов, с использованием } \\
\text { возможностей ГИС-технологий }\end{array}$ \\
\hline
\end{tabular}

В заключение подчеркнем, что для полноценной реализации преимуществ сетевого механизма координации требуется комплексный подход, основанный на оценке совокупного ресурсного потенциала и возможностей комбинирования ограниченных ресурсов в рамках межмуниципального взаимодействия.

\section{Литература}

1. Маслова А. Н. Моногорода в России: проблемы и решения // Контуры глобальных трансформаций: политика, экономика, право. 2011. Т. 4. № 5. С. 16-28.

2. Иванова С. А. Современные проблемы и тенденции социально-экономического развития малых и моногородов // Устойчивое развитие экономики территорий на основе сетевого взаимодействия малых городов и сельских поселений / под ред. М. Ю. Шерешевой. М.: Экономический факультет МГУ, 2018. С. 22-32.

3. Крюкова О. Г., Арсенова Е. В. Влияние мирового финансового кризиса на экономику моногородов // Эффективное антикризисное управление. 2010. № 1. С. 80-89.

4. Фонд развития моногородов. Официальный сайт. Режим доступа: http://www.frmrus.ru/ (дата обращения: 01.02.2018).

5. Клейнер Г. Б. Развитие моногородов и социальная ответственность предприятий // ЭКО. 2007. № 6. С. $187-192$.

6. Шаститко А. Е., Фатихова А. Ф. Моногорода: новый взгляд на старую проблему // Балтийский регион. 2015. № 1. C. 7-35.

7. Мухачёва А. В., Мищук С. Н. Влияние кризиса на качество жизни населения: региональный и временной аспекты // Вестник Кемеровского государственного университета. Серия: Политические, социологические и экономические науки. 2016. № 1. С. 77-82.

8. Шерешева М. Ю., Оборин М. С., Костанян А. А. Особенности оценки качества жизни населения малых городов // Ars Administrandi. Искусство управления. 2017. Т. 9. № 2. С. 289-311.

9. Петрикова Е. М. Комплексная инвестиционная программа развития моногородов // Региональная экономика: теория и практика. 2010. № 43. С. 19-32.

10. Развитие моногородов России / под ред. И. Н. Ильиной. М.: Финансовый университет, 2013. 166 с. 
11. Портал Правительства Тульской области. Режим доступа: https:/tularegion.ru/presscenter/pressrelease/?element_id=79400 (дата обращения: 01.02.2018).

12. Шерешева М. Ю., Оборин М. С., Шимук О. В. Разработка направлений диверсификации сельской экономики в регионах России с учетом потенциала малых городов // Вестник Пермского университета. Серия: Экономика. 2017. Т. 12. № 4. С. 632-648.

13. Антонова И. С. Моделирование инфраструктуры диверсификации экономики моногорода // Вестник Сибирского государственного аэрокосмического университета им. академика М. Ф. Решетнева. 2016. № 17. C. $1104-1112$.

14. Моногорода РФ. Режим доступа: моногорода.рф (дата обращения: 21.01.2018).

15. Иванова С. А., Иванов Н. А. Современные проблемы и тенденции развития сферы туризма и гостеприимства в малых и моногородах // Развитие внутреннего и въездного туризма в России и за рубежом / под ред. М. Ю. Шерешевой. М.: Экономический факультет МГУ, 2017. С. 102-112.

16. Антонов Г. Д., Иванова О. П., Антонова И. С. Подход к управлению проектами диверсификации моногорода (на примере Кузбасса) // Национальные интересы: приоритеты и безопасность. 2012. № 7. С. 15-22.

17. Антонова И. С. Теория диверсификации экономики моногорода // Вестник науки Сибири. 2015. № 2. C. $179-193$.

18. Иванова О. П., Антонова И. С., Антонов Г. Д. Развитие моногородов и управление инвестиционной привлекательностью. М.: Инфра-М, 2016. 234 с.

19. Тамбовцев В. Л. Межмуниципальные взаимодействия с позиций экономического анализа // Terra Economicus. 2017. T. 15. № 3. C. 19-31.

20. Capello R. The city network paradigm: measuring urban network externalities. Urban Studies. 2000. Vol. 37. № 11. P. 1925-1945.

21. Camagni R., Capello R. The City Network Paradigm: Theory and Empirical Evidence // Capello R., Nijkamp P. (ed.) Urban Dynamics and Growth: Advances in Urban Economics (Contributions to Economic Analysis), 2005. Vol. 266. P. 495-529.

22. Courtney P., Errington A. The role of small towns in the local economy and some implications for development policy // Local Economy. 2000. Vol. 15. № 4. P. 280-301.

23. Hinderink J., Titus M. Small towns and regional development: major findings and policy implications from comparative research // Urban Studies. 2002. Vol. 39. № 3. P. 379-391.

24. Mingaleva Z. A., Sheresheva M. Y., Oborin M. S., Gvarliani T. E. Networking of small cities to gain sustainability // Entrepreneurship and Sustainability Issues. 2017. Vol. 5. № 1. P. 140-156.

25. Бобылев С. Н., Порфирьев Б. Н. Устойчивое развитие крупнейших городов и мегаполисов: фактор экосистемных услуг // Вестник Московского университета. Серия 6: Экономика. 2016. № 6. С. 3-21.

26. Hopwood B., Mellor M., O'Brien G. Sustainable development: mapping different approaches // Sustainable development. 2005. Vol. 13. № 1. P.38-52.

27. Taylor P. J. World City Network: A Global Urban Analysis. London: Routledge, 2004.

28. Taylor P. J., Evans D. M., Pain K. 2008. Application of the Interlocking Network Model to Mega-CityRegions: Measuring Polycentricity Within and Beyond CityRegions. Regional Studies. Vol.42. № 8. P. 1079-1093.

29. Christiaensen L., Todo Y. Poverty reduction during the rural-urban transformation-the role of the missing middle // World Development. 2014. № 63. P. 43-58.

30. Ferré C., Ferreira F., Lanjouw P. Is There a Metropolitan Bias? The Relationship between Poverty and City Size in a Selection of Developing Countries // World Bank Economic Review. 2012. Vol. 26. № 3. P. 351-382.

31. Christiaensen L., Weerdt J., Todo Y. Urbanization and poverty reduction: the role of rural diversification and secondary towns // Agricultural Economics. 2013. Vol. 44. № 4-5. P. 435-447.

32. Оборин М. С., Пахалов А. М., Шерешева М. Ю. Эффективность стратегического планирования развития малых городов на основе сетевого механизма координации // Вестник Московского университета. Серия 6: Экономика. 2017. № 4. С. 100-117.

33. Dale B. An institutional approach to local restructuring: the case of four Norwegian mining towns // European Urban and Regional Studies. 2002. Vol. 9. № 1. P. 5-20.

34. Castells M. Globalisation, networking, urbanisation: Reflections on the spatial dynamics of the information age // Urban Studies. 2010. Vol. 47. № 13. P. 2737-2745.

35. Шерешева М. Ю., Колков М. Ю. Роль музеев в развитии туризма с участием малых городов (на примере Владимирской области) // Современные проблемы сервиса и туризма. 2018. Т. 12. № 1. С. 120-133.

36. Гороховец. Все о туризме и отдыхе. Режим доступа: http://gorokhovets.ru/vse-novosti/item/739gorokhovets-stavim-v-prioritet.html (дата обращения: 01.02.2018).

37. Оборин М. С., Шерешева М. Ю., Иванов Н. А. Обоснование стратегических ориентиров социально-экономического развития малых городов России // Вестник Пермского университета. Серия: Экономика. 2017. № 3. C. 437-452.

38. Оборин М. С., Сысоев А. П., Шерешева М. Ю. Некоторые подходы к оценке экономического потенциала малых городов России // Государственное управление. Электронный вестник. 2017. № 63. С. 297-319. 


\title{
DIVERSIFICATION OF SINGLE-INDUSTRY TOWNS' ECONOMY: THE ROLE OF NETWORKING MarinaY. Sheresheva ${ }^{l, @ \text {, * }}$
}

\author{
${ }^{1}$ Lomonosov Moscow State University, 1, Leninskie Gory, Moscow, Russia, 119991 \\ @m.sheresheva@mail.ru
}

Received 02.03.2018. Accepted 27.03.2018.

Keywords: singleindustry towns, small cities, diversification, networking, regional development.

\begin{abstract}
The paper focuses on the diversification of single-industry towns' economy and identifies the role of networking in this process. The author presents preliminary results of the Russian Science Foundation project "Sustainable development of the territorial economy through networking of small cities and district centers". The goal of the project is to identify opportunities to overcome the growing gap in the level and quality of life in small Russian towns vs. large cities and megacities, and to propose measures for combining resources and competencies of small cities in the framework of network relationships. The cases of Tula, Vladimir and Perm regions were in the focus of research. To achieve the research goal, a set of methods was applicable, including system analysis, formal logical method, dialectical method, as well as quantitative and qualitative marketing research. This allows us to draw conclusions about the presence of structural problems and contemporary trends, and to offer recommendations taking into account the specialization of small singleindustry towns. Serious problems faced by the municipalities of single-industry towns, and the obstacles to efficient inter-municipal cooperation have been identified. At the same time, international evidence shows that the formation of a favorable institutional environment for mutually beneficial combination of resources and competences of singleindustry towns with different specialization facilitates the implementation of joint projects and makes it possible to accelerate the processes of economic diversification by using the benefits of a network coordination mechanism.
\end{abstract}

For citation: Sheresheva M. Y. Diversifikatsiia ekonomiki malykh monogorodov: rol' setevykh vzaimodeistvii [Diversification of Single-Industry Towns' Economy: the Role of Networking]. Bulletin of Kemerovo State University. Series: Political, Sociological andEconomic Sciences,no.2(2018): 162-171.DOI:10.21603/2500-3372-2018-2-162-171.

\section{References}

1. Maslova A. N. Monogoroda v Rossii: problemy i resheniia [Monocities in Russia: problems and solutions]. Kontury global'nykh transformatsii: politika, ekonomika, pravo = Contours of global transformations: politics, economics, law, 4, no. 5 (2011): 16-28.

2. Ivanova S. A. Sovremennye problemy i tendentsii sotsial'no-ekonomicheskogo razvitiia malykh i monogorodov [Modern problems and tendencies of social and economic development of small and single-industry towns]. Ustoichivoe razvitie ekonomiki territorii na osnove setevogo vzaimodeistviia malykh gorodov i sel'skikh poselenii [Sustainable development of territories economy on the basis of network interaction of small towns and rural settlements]. Ed. Sheresheva M. Y. Moscow: Ekonomicheskii fakul'tet MGU, 2018, 22-32.

3. Kriukova O. G., Arsenova E. V. Vliianie mirovogo finansovogo krizisa na ekonomiku monogorodov [Influence of the world financial crisis on monocities economy]. Effektivnoe antikrizisnoe upravlenie = Effective anti-crisis management, no. 1 (2010): 80-89.

4. Fond razvitiia monogorodov [Mono-city Development Fund]. Available at: http://www.frmrus.ru/ (accessed 01.02.2018).

5. Kleiner G. B. Razvitie monogorodov i sotsial'naia otvetstvennost' predpriiatii [The development of singleindustry towns and the social responsibility of enterprises]. $E K O=E C O$, no. 6 (2007): 187-192.

6. Shastitko A. E., Fatikhova A. F. Monogoroda: novyi vzgliad na staruiu problemu [The Monotown: A New View of the Old Problem]. Baltiiskii region = The Baltic Region, no. 1 (2015): 7-35.

7. Mukhacheva A. V., Mishchuk S. N. Vliianie krizisa na kachestvo zhizni naseleniia: regional'nyi i vremennoi aspekty [The impact of the crisis on the quality of life of the population: regional and temporal aspects]. Bulletin of the Kemerovo State University. Series: Political, sociological and economic sciences, no. 1 (2016): 77-82.

\footnotetext{
* The article was prepared in the framework of scientific research carried out with the financial support of the grant of the Russian Science Foundation (project No. 17-18-01324) "Sustainable development of the economy of territories based on the network interaction of small towns and district centers".
} 
8. Sheresheva M. Y., Oborin M. S., Kostanian A. A. Osobennosti otsenki kachestva zhizni naseleniia malykh gorodov [Peculiarities of assessing the quality of life of the population of small towns]. Ars Administrandi. Iskusstvo upravleniia = Ars Administrandi. The Art of Management, 9, no. 2 (2017): 289-311.

9. Petrikova E. M. Kompleksnaia investitsionnaia programma razvitiia monogorodov [Complex investment program for single-industry development]. Regional'naia ekonomika: teoriia i praktika = Regional economy: theory and practice, no. 43 (2010): 19-32.

10. Razvitie monogorodov Rossii [Development of Russian monocities]. Ed. Il'ina I. N. Moscow: Finansovyi universitet, 2013, 166.

11. Portal Pravitel'stva Tul'skoi oblasti [Portal of the Government of the Tula region]. Available at: https:// tularegion.ru/presscenter/press-release/?ELEMENT_ID=79400 (accessed 01.02.2018).

12. Sheresheva M. Y., Oborin M. S., Shimuk O. V. Razrabotka napravlenii diversifikatsii sel'skoi ekonomiki $\mathrm{v}$ regionakh Rossii s uchetom potentsiala malykh gorodov [Development of directions of diversification of rural economy in Russian regions taking into account the potential of small towns]. Vestnik Permskogo universiteta. Seriia: Ekonomika = Bulletin of Perm University. Series: The Economy, 12, no. 4 (2017): 632-648.

13. Antonova I. S. Modelirovanie infrastruktury diversifikatsii ekonomiki monogoroda [Simulation of the infrastructure of diversification of monotown economy]. Vestnik Sibirskogo gosudarstvennogo aerokosmicheskogo universiteta im. akademika M. F. Reshetneva = Vestnik of the Siberian State Aerospace University named after Academician M. F. Reshetnev, no. 17 (2016): 1104-1112.

14. Monogoroda RF [Monocity of the Russian Federation]. Available at: моногорода.рф (accessed 21.01.2018).

15. Ivanova S. A., Ivanov N. A. Sovremennye problemy i tendentsii razvitiia sfery turizma i gostepriimstva v malykh i monogorodakh [Modern problems and tendencies of development of tourism and hospitality in small and singleindustry cities]. Razvitie vnutrennego $i$ v"ezdnogo turizma $v$ Rossii i za rubezhom [Development of domestic and incoming tourism in Russia and abroad]. Ed. Sheresheva M. Y. Moscow: Ekonomicheskii fakul'tet MGU, 2017, $102-112$.

16. Antonov G. D., Ivanova O. P., Antonova I. S. Podkhod k upravleniiu proektami diversifikatsii monogoroda (na primere Kuzbassa) [Approach to the management of projects for the diversification of single-industry towns (on the example of Kuzbass)]. Natsional'nye interesy: prioritety $i$ bezopasnost' $=$ National interests: priorities and security, no. 7 (2012): 15-22.

17. Antonova I. S. Teoriia diversifikatsii ekonomiki monogoroda [Theory of diversification of monotown economy]. Vestnik nauki Sibiri = Bulletin of Siberian Science, no. 2 (2015): 179-193.

18. Ivanova O. P., Antonova I. S., Antonov G. D. Razvitie monogorodov i upravlenie investitsionnoi privlekatel'nost'iu [Development of single-industry towns and management of investment attractiveness]. Moscow: Infra-M, $2016,234$.

19. Tambovtsev V. L. Mezhmunitsipal'nye vzaimodeistviia s pozitsii ekonomicheskogo analiza [Intermunicipal interactions from the standpoint of economic analysis]. Terra Economicus, 15, no. 3 (2017): 19-31.

20. Capello R. The city network paradigm: measuring urban network externalities. Urban Studies, 37 , no. 11 (2000): 1925-1945.

21. Camagni R., Capello R. The City Network Paradigm: Theory and Empirical Evidence. Capello R., Nijkamp P. (ed.) Urban Dynamics and Growth: Advances in Urban Economics (Contributions to Economic Analysis), vol. 266 (2005): 495-529.

22. Courtney P., Errington A. The role of small towns in the local economy and some implications for development policy. Local Economy, 15, no. 4 (2000): 280-301.

23. Hinderink J., Titus M. Small towns and regional development: major findings and policy implications from comparative research. Urban Studies, 39, no. 3 (2002): 379-391.

24. Mingaleva Z. A., Sheresheva M. Y., Oborin M. S., Gvarliani T. E. Networking of small cities to gain sustainability. Entrepreneurship and Sustainability Issues, 5, no. 1 (2017): 140-156.

25. Bobylev S. N., Porfir'ev B. N. Ustoichivoe razvitie krupneishikh gorodov i megapolisov: faktor ekosistemnykh uslug [Sustainable development of the largest cities and megacities: the factor of ecosystem services]. Vestnik Moskovskogo universiteta. Seriia 6: Ekonomika = Bulletin of Moscow University. Series 6: Economics, no. 6 (2016): 3-21.

26. Hopwood B., Mellor M., O'Brien G. Sustainable development: mapping different approaches. Sustainable development, 13, no. 1 (2005): 38-52.

27. Taylor P. J. World City Network: A Global Urban Analysis. London: Routledge, 2004.

28. Taylor P. J., Evans D. M., Pain K. Application of the Interlocking Network Model to Mega-City-Regions: Measuring Polycentricity Within and Beyond CityRegions. Regional Studies. 2008, vol. 42, no. 8, 1079-1093.

29. Christiaensen L., Todo Y. Poverty reduction during the rural-urban transformation-the role of the missing middle. World Development, no. 63 (2014): 43-58.

30. Ferré C., Ferreira F., Lanjouw P. Is There a Metropolitan Bias? The Relationship between Poverty and City Size in a Selection of Developing Countries. World Bank Economic Review, 26, no. 3 (2012): 351-382.

31. Christiaensen L., Weerdt J., Todo Y. Urbanization and poverty reduction: the role of rural diversification and secondary towns. Agricultural Economics, 44, no. 4-5 (2013): 435-447.

32. Oborin M. S., Pakhalov A. M., Sheresheva M. Y. Effektivnost' strategicheskogo planirovaniia razvitiia malykh gorodov na osnove setevogo mekhanizma koordinatsii [Efficiency of strategic planning of development 
of small towns on the basis of network coordination mechanism]. Vestnik Moskovskogo universiteta. Seriia 6: Ekonomika = Bulletin of Moscow University. Series 6: Economics, no. 4 (2017): 100-117.

33. Dale B. An institutional approach to local restructuring: the case of four Norwegian mining towns. European Urban and Regional Studies, 9, no. 1 (2002): 5-20.

34. Castells M. Globalisation, networking, urbanisation: Reflections on the spatial dynamics of the information age. Urban Studies, 47, no. 13 (2010): 2737-2745.

35. Sheresheva M. Y., Kolkov M. Iu. Rol' muzeev v razvitii turizma s uchastiem malykh gorodov (na primere Vladimirskoi oblasti) [The role of museums in the development of tourism with the participation of small towns (on the example of the Vladimir region)]. Sovremennye problemy servisa i turizma $=$ Modern problems of service and tourism, 12, no. 1 (2018): 120-133.

36. Gorokhovets. Vse o turizme $i$ otdykhe [Gorokhovets. All about tourism and recreation]. Available at: http:// gorokhovets.ru/vse-novosti/item/739-gorokhovets-stavim-v-prioritet.html (accessed 01.02.2018).

37. Oborin M. S., Sheresheva M. Y., Ivanov N. A. Obosnovanie strategicheskikh orientirov sotsial'noekonomicheskogo razvitiia malykh gorodov Rossii [The substantiation of strategic landmarks of social and economic development of small cities of Russia]. Vestnik Permskogo universiteta. Seriia: Ekonomika = Bulletin of Perm University. Series: The Economy, no. 3 (2017): 437-452.

38. Oborin M. S., Sysoev A. P., Sheresheva M. Y. Nekotorye podkhody k otsenke ekonomicheskogo potentsiala malykh gorodov Rossii [Some approaches to assessing the economic potential of small cities of Russia]. Gosudarstvennoe upravlenie. Elektronnyi vestnik = Public administration. Electronic Herald, no. 63 (2017): 297-319. 